\title{
Childhood Cerebellar Neoplasm
}

National Cancer Institute

\section{Source}

National Cancer Institute. Childhood Cerebellar Neoplasm. NCI Thesaurus. Code C5970.

A neoplasm that affects the cerebellum and occurs during childhood. 